Jurnal Tanah dan Sumberdaya Lahan Vol 8 No 1: 149-160, 2021

e-ISSN:2549-9793, doi: 10.21776/ub.jts1.2021.008.1.18

\title{
EVALUASI KESESUAIAN LAHAN TANAMAN JAGUNG PADA LAHAN KERING DI KECAMATAN WAGIR KABUPATEN MALANG
}

\section{Land Suitability Evaluation for Maize in Dry Land Wagir District, Malang Regency}

\author{
Mei Ridayanti, Mochtar Lutfi Rayes, Christanti Agustina* \\ Jurusan Tanah, Fakultas Pertanian, Universitas Brawijaya, Jl. Veteran No.1, Malang, 65145 \\ *Penulis korespondensi: christanti.ag@ub.ac.id
}

\begin{abstract}
Malang Regency has a large area of dry land and currently being developed as a centre for food crops, especially maize. Maize production in Malang Regency has not provided high productivity, one of which is in Wagir District. This study aimed to determine the actual land suitability class, determine the characteristics of the land that affects the productivity of maize, determine the actual productivity class of maize, and develop new land suitability criteria using the boundary line method. This study was conducted using a physiographic survey method based on the Land Mapping Unit. Soil samples were taken at a depth of $0-120 \mathrm{~cm}$ (mini pit and drilling) at each observation points (42 points) and analyzed in the laboratory (texture, $\mathrm{pH}, \mathrm{CEC}, \mathrm{C}$-Organic, $\mathrm{BS}, \mathrm{N}$-total, $\mathrm{P}_{2} \mathrm{O}_{5}$, Potassium, $\mathrm{Ca}, \mathrm{Mg}$, and $\mathrm{Na}$ ). The determination of land suitability class was carried out using the SPKL (Sistem Penilaian Kesesuaian Lahan) application and the modification of the criteria was carried out using the boundary line method. The results of the land suitability evaluation included in class $\mathrm{S} 3$ and $\mathrm{N}$, with limiting factors of rainfall, base saturation, $\mathrm{pH}$, organic- $\mathrm{C}$, total $\mathrm{N}, \mathrm{P}_{2} \mathrm{O}_{5}$, potassium, slope and erosion hazard. The stepwise analysis result showed that slope and air temperature determined maize productivity in the study area. Boundary lines analysis gave results that modified suitability classified as S3 and N which is the same category as actual suitability classes.
\end{abstract}

Keywords: dry land, land suitability, maize productivity, modification

\section{Pendahuluan}

Lahan kering di Kabupaten Malang tercatat seluas 10.639 ha (BPS, 2017) dan saat ini dikembangkan sebagai sentra tanaman pangan, khususnya jagung. Jagung merupakan salah satu serealia yang memiliki nilai ekonomi tinggi dan mempunyai peluang besar untuk dikembangkan. Meskipun tercatat memiliki luasan lahan kering yang luas, tidak lantas budidaya jagung di Kabupaten Malang menghasilkan produksi yang tinggi. Selama empat tahun terakhir, produksi jagung di Kabupaten Malang mengalami penurunan dari $306.479 \mathrm{t}$ menjadi $260.568 \mathrm{t}$ (BPS, 2017). Kecamatan Wagir merupakan salah satu kecamatan penghasil jagung di Kabupaten Malang yang produksinya tergolong rendah.
Selama rentang waktu 5 tahun, yaitu pada tahun 2013-2017 produksi jagung di Kecamatan Wagir masih fluktuatif. Banyak faktor yang menyebabkan penurunan produksi jagung di Kecamatan Wagir. Menurut wawancara terhadap kelompok tani di Desa Dalisodo, Kecamatan Wagir, produksi jagung di lahan mereka menunjukkan ketidakmerataan hasil meskipun dengan manajemen dan input yang sama. Penurunan produksi jagung di Kecamatan Wagir juga tidak berbanding lurus dengan peningkatan luas lahan. BPS (2017) mencatat selama rentang waktu 4 tahun terakhir, di Kecamatan Wagir produktivitas jagung turun sebesar 2,7 $\mathrm{t}$ ha ${ }^{-1}$ meskipun terdapat penambahan luasan lahan jagung sebesar 361 


\section{Jurnal Tanah dan Sumberdaya Lahan Vol 8 No 1: 149-160, 2021 e-ISSN:2549-9793, doi: 10.21776/ub.jts1.2021.008.1.18}

ha. Adanya ketidakseimbangan antara produksi jagung dengan luas lahan berakibat pada munculnya pertanyaan mengenai apa yang menjadi penyebab hal tersebut, sehingga perlu dilakukan kajian mendalam mengenai kesesuaian lahan untuk tanaman jagung di Kecamatan Wagir agar diketahui kelas kesesuaian lahan aktual, karakteristik lahan yang berpengaruh pada produktivitas jagung, kelas produktivitas aktual tanaman jagung, sehingga dapat dilakukan penyusunan kriteria kesesuaian lahan baru untuk tanaman Jagung di Kecamatan Wagir, Kabupaten Malang.

\section{Bahan dan Metode}

\section{Waktu dan tempat penelitian}

Penelitian dilaksanakan pada bulan Mei sampai Desember 2019 di Kecamatan Wagir, Kaupaten Malang, Propinsi Jawa Timur. Analisis tanah dilakukan di Laboratorium Fisika dan Kimia Jurusan Tanah Fakultas Pertanian Universitas Brawijaya.

\section{Alat dan bahan}

Alat yang digunakan adalah laptop ASUS X455L, Microsoft Office 2013, Software ArcGIS 10.3, SAGA GIS 2.3, PCI Geomatics 2013, SPKL 2.0, SPSS versi 25, survei set, GPS (Global Positioning System), peralatan analisis laboratorium, dan kamera. Bahan yang digunakan adalah contoh tanah, Peta Rupa Bumi Indonesia Lembar Malang skala 1:25.000, Peta Geologi Lembar Malang skala 1:100.000, Peta Geologi Lembar Turen skala 1:100.000, digital elevation model DEM 12,5 meter ALOS PALSAR, Citra Satelit Landsat 8 OLI/TIRS Path/Row 188/66 tanggal perekaman 5 Maret 2019, bahan analisis laboratorium, form pengamatan morfologi dan fisiografi, plastik serta kertas label.

\section{Pelaksanaan penelitian}

Penelitian dilaksanakan denganmenggunakan metode survei secara fisiografi dengan tingkat survei semi detail (skala 1:50.000) berdasarkan perbedaan satuan peta lahan (SPL). Satuan peta lahan disusun dari hasil tumpang tindih peta geologi, landform, kelerengan, relief serta peta penggunaan lahan tegalan. Setiap satuan lahan yang berbeda akan dipilih satu titik pengamatan sebagai pewakil untuk pengambilan data lapangan. Tahapan penelitian dibagi menjadi tiga yaitu pra survei, survei, serta pasca survei. Pada tahap pra survei dibagi menjadi tiga tahap yaitu pengumpulan data sekunder dan pembuatan peta SPL, serta penentuan titik pengamatan berdasarkan perbedaan bentuk SPL dan aksesibilitas. Titik pengamatan di lokasi penelitian ditentukan sebanyak 42 titik yang tersebar dalam 8 (delapan) SPL. Pengambilan data lapangan dilakukan pada tahap survei. Data karakteristik lahan diamati melalui pengamatan fisiografi dan morfologi lahan serta Pengambilan data lapangan dilakukan pada tahap survei. Data karakteristik lahan diamati melalui pengambilan data produksi aktual. Data fisiografi lahan terdiri dari koordinat, aliran permukaan, drainase, genangan/banjir, erosi, bahaya erosi, penggunaan lahan, vegetasi, rezim lengas tanah, rezim suhu tanah, relief dan lereng. Data morfologi tanah terdiri dari warna, struktur, konsistensi, tekstur, akar, pori, dan batas horizon. Pengamatan morfologi tanah dilakukan dengan membuat minipit dengan ukuran $50 \times 50 \mathrm{~cm}$ (sampai batas epipedon dan endopedon terlihat) dan apabila memungkinkan maka dilakukan pemboran sampai kedalaman $120 \mathrm{~cm}$. Setelah dilakukan pengamatan morfologi tanah, berikutnya dilakukan pengambilan contoh tanah terganggu. Setiap contoh tanah dilakukan uji laboratorium di Laboratorium Fisika dan Kimia Tanah, Jurusan Tanah, Fakultas Pertanian, Universitas Brawijaya. Data produksi tanaman jagung diukur di lapangan melalui pembuatan peta ubinan dengan ukuran $1 \times 1 \mathrm{~m}$ pada tanaman yang siap panen, lalu ditimbang berat panen dalam petak dan dilanjutkan dengan konversi produksi dalam satuan hektar Selanjutnya pada tahap pasca survei, scontoh tanah yang telah didapatkan dilakukan analisis laboratorium berupa analisis tekstur (metode pipet) (Sudjadi dan Widjik, 1971), $\mathrm{pH}\left(\mathrm{H}_{2} \mathrm{O}\right.$ dan $\left.\mathrm{NaF}\right)$ (Isric, 1993), KTK (Ekstraksi $\mathrm{NH}_{4} \mathrm{Oac} 1 \mathrm{~N}$ pH7) (Hajek et al., 1972), C-Organik (Walkley \& Black) (Association of Official Agriculture Chemists, 2002) KB (Ekstraksi NH4Oac $1 \mathrm{~N}$ pH7) (Hajek et al., 1972), $\mathrm{P}_{2} \mathrm{O}_{5}$ (P-Bray1) (Bray and Kurtz, 1945), N-total (Destilasi makro Kjeldahl) (Association of Official Agriculture Chemists, 2002). 


\section{Jurnal Tanah dan Sumberdaya Lahan Vol 8 No 1: 149-160, 2021 e-ISSN:2549-9793, doi: 10.21776/ub.jts1.2021.008.1.18}

Tabel 1. Kriteria kesesuaian lahan untuk tanaman jagung.

\begin{tabular}{|c|c|c|c|c|}
\hline \multirow[t]{2}{*}{ Karakteristik Lahan } & \multicolumn{4}{|c|}{ Kelas Kesesuaian Lahan } \\
\hline & S1 & S2 & S3 & $\mathbf{N}$ \\
\hline Temperatur (tc) & & & $16-20$ & $<16$ \\
\hline Temperatur rerata $\left({ }^{\circ} \mathrm{C}\right)$ & $20-26$ & $26-30$ & $30-32$ & $>32$ \\
\hline Ketersediaan air (wa) & & $1200-1600$ & $>1600$ & \\
\hline Curah hujan tahunan (mm) & $900-1200$ & $500-900$ & $300-500$ & $<300$ \\
\hline Kelembaban (\%) & $>42$ & $36-42$ & $30-36$ & $<30$ \\
\hline $\begin{array}{l}\text { Ketersediaan oksigen (oa) } \\
\text { Drainase }\end{array}$ & Baik, sedang & $\begin{array}{c}\text { Agak cepat, } \\
\text { agak terhambat }\end{array}$ & Terhambat & $\begin{array}{c}\text { Sangat } \\
\text { terhambat, } \\
\text { cepat }\end{array}$ \\
\hline Media perakaran (rc) & & & & \\
\hline $\begin{array}{l}\text { Tekstur } \\
\text { Bahan kasar }(\%) \\
\text { Kedalaman tanah }(\mathrm{cm})\end{array}$ & $\begin{array}{l}\text { h, ah, s } \\
\quad<15 \\
\quad>60\end{array}$ & $\begin{array}{l}\text { h, ah, s } \\
15-35 \\
40-60\end{array}$ & $\begin{array}{c}\mathrm{ak} \\
35-55 \\
25-40\end{array}$ & $\begin{aligned} & \mathrm{k} \\
> & 55 \\
< & 25\end{aligned}$ \\
\hline Retensi hara (nr) & & & & \\
\hline $\begin{array}{l}\left.\text { KTK tanah (me } 100 \mathrm{~g}^{-1}\right) \\
\text { Kejenuhan basa }(\%) \\
\mathrm{pH} \mathrm{H}{ }_{2} \mathrm{O}\end{array}$ & $\begin{array}{c}>16 \\
>50 \\
5,8-7,8\end{array}$ & $\begin{array}{c}5-16 \\
35-50 \\
5,5-5,8 \\
7,8-8,2\end{array}$ & $\begin{array}{l}<5 \\
<35 \\
<5,5 \\
>8,2\end{array}$ & \\
\hline C-organik & $>1,2$ & $0,8-1,2$ & $<0,8$ & \\
\hline $\begin{array}{l}\text { Hara Tersedia (na)* } \\
\mathrm{N} \text { total }(\%) \\
\mathrm{P}_{2} \mathrm{O}_{5}\left(\mathrm{mg} 100 \mathrm{~g}^{-1}\right) \\
\mathrm{K}\left(\mathrm{me} 100 \mathrm{~g}^{-1}\right)\end{array}$ & $\begin{array}{l}0,21-0,5 \\
11-15 \\
0,6-1,0\end{array}$ & $\begin{array}{c}0,1-0,2 \\
8-10 \\
0,4-0,5\end{array}$ & $\begin{array}{l}<0,1 \\
\leq 7 \\
<0,3\end{array}$ & \\
\hline $\begin{array}{l}\text { Bahaya erosi (eh) } \\
\text { Lereng }(\%) \\
\text { Bahaya erosi }\end{array}$ & $\begin{array}{c}<3 \\
\mathrm{t}\end{array}$ & $\begin{array}{c}3-8 \\
\text { sr }\end{array}$ & $\begin{array}{l}8-15 \\
\text { r-sd }\end{array}$ & $\begin{array}{l}>15 \\
b-s b\end{array}$ \\
\hline
\end{tabular}

Keterangan : $\left(^{*}\right)$ nilai kriteria berdasarkan Balittan (2018) ; Tekstur $\mathrm{h}=$ halus ; ah=agak halus ; s=sedang ; ak=agak kasar ; Bahaya erosi $\mathrm{t}=$ tanpa; $\mathrm{sr}=$ sangat ringan; $\mathrm{r}=$ ringan; $\mathrm{sd}=$ sedang; $\mathrm{b}=$ berat; $\mathrm{sb}=$ sangat berat ; Hara tersedia sr=sangat rendah ; r=rendah ; $=$ sedang ; $\mathrm{t}=$ tinggi (Ritung et al., (2011)

Data hasil pengamatan selanjutnya dilakukan interpretasi data untuk klasifikasi tanah, kesesuaian lahan aktual, menilai karakteristik lahan yang berpengaruh pada produksi tanaman, menentukan kelas kesesuaian produksi tanaman dan menentukan kriteria baru kesesuaian lahan. Klasifikasi tanah mengacu pada Kunci Taksonomi Tanah tahun 2014 (Soil Survey Staff, 2014). Klasifikasi kesesuaian lahan mengacu pada metode matching antara data karakteristik lahan dengan syarat tumbuh tanaman menurut Ritung et al. (2011), dengan kriteria tersaji pada Tabel 1. Penilaian kesesuaian lahan menggunakan software SPKL 2.0. Karakteristik lahan yang paling mempengaruhi produksi jagung ditentukan dengan metode regresi berganda yaitu stepwise analysis menggunakan software SPSS versi 25.0. Kelas produktivitas tanaman dikelompokkan berdasarkan nilai produksi tanaman yang mengacu pada FAO (1976) (Tabel 2). Penentuan kriteria baru kesesuaian lahan menggunakan metode boundary line yang mengacu pada hasil analisis karakteristik lahan yang paling memberikan pengaruh pada produktivitas tanaman (pustaka). 


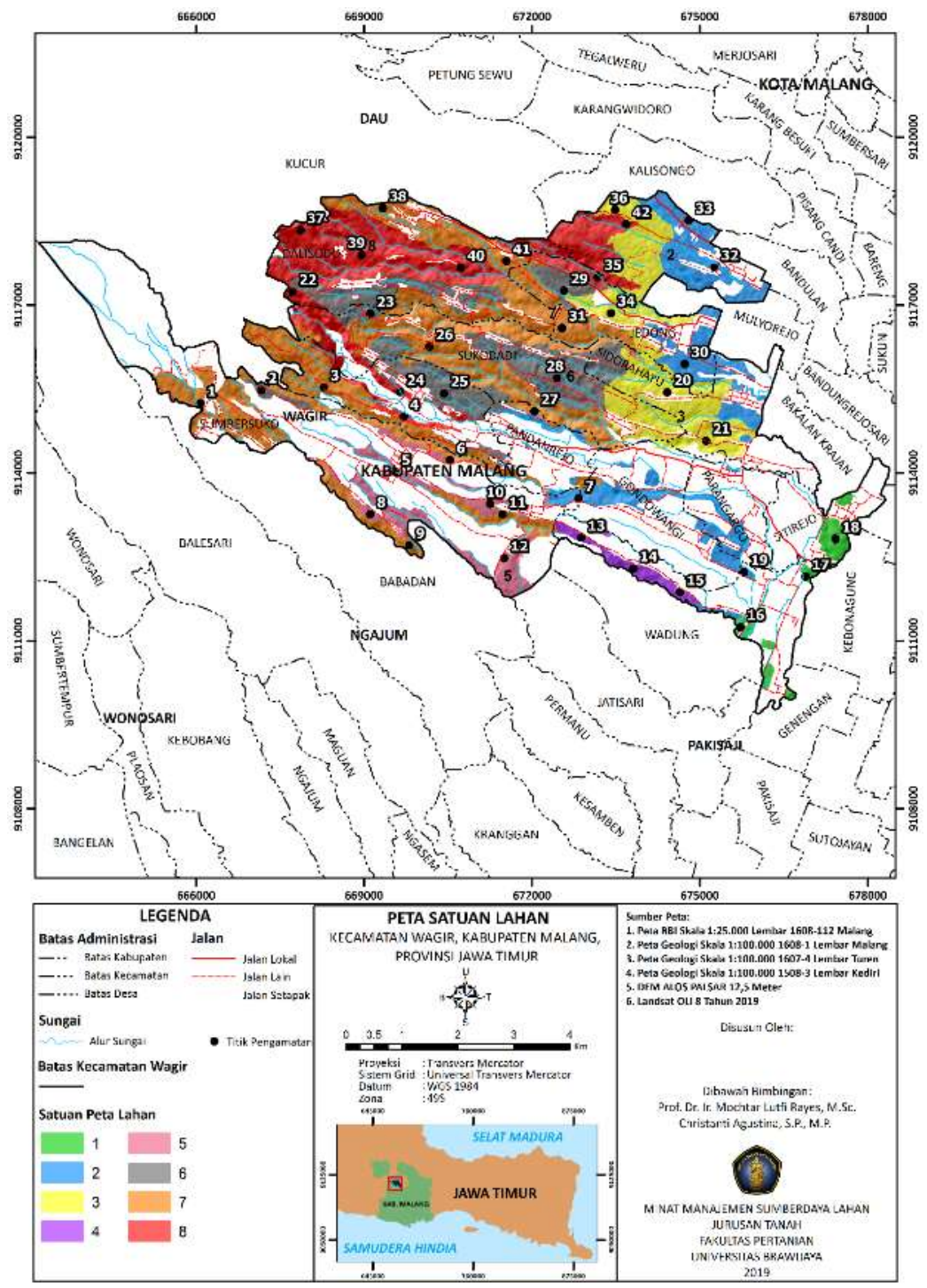

Gambar 1. Peta SPL Kecamatan Wagir

Tabel 2. Klasifikasi kelas kesesuaian produksi.

\begin{tabular}{ccc}
\hline No & Persentase Produksi & KKL \\
\hline 1 & $80-100 \%$ & S1 \\
2 & $60-80 \%$ & S2 \\
3 & $40-60 \%$ & S3 \\
4 & $<40 \%$ & $\mathrm{~N}$ \\
\hline
\end{tabular}

Keterangan : KKL : Kelas Kesesuaian Lahan

\section{Kondisi umum wilayah}

\section{Lokasi penelitian}

Secara astronomis, daerah penelitian berada pada zona 49 UTM pada 668299 - 677121 mT dan 9111753 - 9117990 mU. Secara geografis, wilayah penelitian berada pada lereng Gunung Kawi, tepatnya di Kecamatan Wagir, Kabupaten Malang.

Geologi

Berdasarkan Peta Geologi skala 1:100.000 Lembar Malang dan Lembar Turen, Kecamatan Wagir tersusun oleh 3 formasi geologi yaitu formasi geologi endapan tuf Malang (Qptm), formasi geologi endapan gunung api KawiButak (Qpkb), dan formasi geologi lava kerucut katu (Qlk). Formasi geologi endapan tuf Malang (Qptm) tersusun atas endapan tuf, yang terdiri 


\section{Jurnal Tanah dan Sumberdaya Lahan Vol 8 No 1: 149-160, 2021 e-ISSN:2549-9793, doi: 10.21776/ub.jts1.2021.008.1.18}

dari tuf lapili, tuf batu apung, dan lava. Formasi geologi endapan gunung api Kawi-Butak (Qpkb) memiliki material penyusun yang terdiri atas lava andesit-basal piroksen, breksi dan tuf pasiran. Kemudian formasi geologi lava kerucut katu (Qlk) yang memiliki meterial penyusun lava andesit piroksen.

\section{Lereng, relief dan elevasi}

Berdasarkan hasil analisi DEM ALOS PALSAR 12,5 m Kecamatan Wagir, Kabupaten Malang memiliki 5 kelas kelerengan yaitu kelas datar $(0-$ $1 \%$ ), kelas landai (3-8\%), kelas berombak (8$15 \%$ ), kelas bergelombang (15-25\%), dan kelas agak curam (25-40\%). Relief yang ditemukan pada lokasi penelitian adalah datar, berombak, bergelombang, berbukit kecil, dan berbukit serta kelas ketinggian tempat yaitu antara $400-2.000$ $\mathrm{m}$.

\section{Kondisi iklim}

Pola curah hujan di lokasi penelitian dianalisis berdasarkan data curah hujan yang dicatat oleh Stasiun Hujan Gondowangi yang terletak di Desa Gondowangi, Kecamatan Wagir, Kabupaten Malang. Hasil analisis menunjukkan bahwa Kecamatan Wagir memiliki rata-rata curah hujan selama 10 tahun (2009-2018)

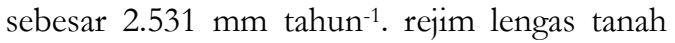
udik dan rejim suhu tanah isohipertermik dengan rata-rata suhu tanah tahunan bernilai $22^{\circ}$ $\mathrm{C}$ atau lebih.

\section{Penggunaan lahan}

Kecamatan Wagir memiliki lahan hutan seluas 239,77 ha dengan presentase sebesar 3,85\%, kemudian lahan agroforestri seluas 909,95 ha dengan presentase sebesar 14,61 \%. Lahan pemukiman di Kecamatan Wagir seluas 588,36 ha dengan presentase sebesar 9,45\%. Lahan sawah seluas 921,45 ha dengan presentase 14,80 $\%$, semak belukar seluas 331,80 ha dengan presentase $5,33 \%$, dan tegalan seluas 3.236,42 ha dengan presentase $51,9 \%$.

\section{Taksa tanah}

Hasil klasifikasi tanah menunjukkan bahwa Kecamatan Wagir Kabupaten Malang terdiri atas 2 ordo tanah (Inceptisols dan Andisol), 2 sub ordo tanah (udepts dan udands), 3 grup tanah (Dystrudepts, Humudepts, dan Hapludands), dan 4 sub grup tanah dari tanah
(Typic Dystrudepts, Typic Humudepts, Humic Dystrudepts dan Typic Hapludans). Tanah dengan sub grup Typic Dystrudepts memiliki epipedon okrik dan endopedon kambik, $\mathrm{pH}$ berada di kisaran 4,65 sampai 5,90, dan nilai kejenuhan basa antara 17 sampai 49\%. Tanah dengan sub grup Typic Humudepts memiliki epipedon umbrik dan endopedon kambik dan nilai kejenuhan basa antara 22 sampai $43 \%$ pada semua bagian epipedon, $\mathrm{pH}$ tanah berkisar antara 4,41 sampai 5,68, serta kadar C-Organik $1,1-2,53 \%$. Tanah dengan sub grup Humic Dystrudepts memiliki epipedon umbrik serta endopedon kambik, memiliki nilai kejenuhan basa kurang berkisar antara 19-45\%, memiliki nilai $\mathrm{pH}$ 4,47-5,20. Tanah dengan sub grup Typic Hapludands memiliki nilai kejenuhan basa 47\%, kadar C-Organik sebesar 1,25\%, serta nilai $\mathrm{pH} \mathrm{NaF}$ sebesar 11,60.

Satuan peta tanah

Hasil interpretasi data menunjukkan bahwa terdapat tiga kelompok satuan peta tanah yang dijumpai di lokasi penelitian, yaitu konsosiasi, asosiasi, dan komplek. Ketiga satuan tersebut memuat beberapa jenis tanah dan dihasilkan 8 (delapan) SPT, antara lain: SPT 1 - Konsosiasi Typic Dystrudepts, berada pada lahan dengan landform vulkan bawah, lereng berkisar antara 0-1\%, dan relief datar. SPT 2 - Konsosiasi Typic Humudepts, berada pada lahan dengan landform vulkan bawah, lereng berkisar antara 3-8\%, dan relief berombak. SPT 3 - Asosiasi Typic Dystrudepts dan Typic Humudepts, berada pada lahan dengan landform vulkan bawah, lereng berkisar antara 8-15\%, dan relief bergelombang. SPT 4 - Asosiasi Typic Humudepts dan Humic Dystrudepts, berada pada lahan dengan landform vulkan bawah, lereng berkisar antara 15-25\%, dan relief berbukit kecil. SPT 5 - Asosiasi Typic Dystrudepts, Typic Humudepts dan Humic Dystrudepts, berada pada lahan dengan landform vulkan tengah, lereng berkisar antara 3-8\%, dan relief berombak. SPT 6 - Kompleks Typic Humudepts, Typic Dystrudepts dan Humic Dystrudepts, berada pada lahan dengan landform vulkan tengah, lereng berkisar anatara 8-15\%, dan relief bergelombang. SPT 7 Kompleks Humic Dystrudepts, Typic Humudepts dan Typic Hapludands, berada pada lahan dengan landform vulkan tengah, lereng 


\section{Jurnal Tanah dan Sumberdaya Lahan Vol 8 No 1: 149-160, 2021 e-ISSN:2549-9793, doi: 10.21776/ub.jts1.2021.008.1.18}

berkisar antara 15-25\%, dan relief berbukit. SPT 8 - Kompleks Humic Dystrudepts, Typic Humudepts dan Typic Dystrudepts, berada pada lahan dengan landform vulkan tengah, lereng berkisar antara 25-40\%, dan relief berbukit.

\section{Hasil dan Pembahasan}

\section{Karakteristik lahan di lokasi penelitian}

Suhu udara di lokasi penelitian berkisar antara $20^{\circ} \mathrm{C}-24^{\circ} \mathrm{C}$ dan berdasarkan kriteria Ritung et al. (2011) temperatur rerata pada seluruh SPT di lokasi penelitian termasuk ke dalam kelas kesesuaian S1. (Tabel 3). Curah hujan rata- rata di Kecamatan Wagir Kabupaten Malang adalah sebesar $2351 \mathrm{~mm}$ tahun $^{-1}$ sehingga termasuk ke dalam kelas kesesuaian S3. Ketersediaan oksigen di tanah dipengaruhi oleh drainase. Berdasarkan kriteria Ritung et al. (2011) kondisi drainase pada lokasi penelitian termasuk ke dalam kelas kesesuaian lahan S1 dan S2 (Tabel 3). Media perakaran dalam evaluasi lahan dipengaruhi oleh karakteristik lahan berupa kedalaman tanah dan tekstur. Kedalaman tanah pada lokasi penelitian adalah $>100 \mathrm{~cm}$ sehingga pada seluruh SPT termasuk ke dalam kelas kesesuaian S1 (Tabel 3). Tekstur tanah pada seluruh SPT termasuk ke dalam kelas S1 (Tabel 3). Kemampuan tanah menahan unsur hara dipengaruhi oleh empat karakteristik lahan yaitu Kapasitas Tukar Kation, Kejenuhan Basa, pH, dan kadar C-Organik. Hasil penelitian menunjukkan bahwa nilai Kapasitas Tukar Kation (KTK) pada daerah penelitan berkisar antara 20,67 sampai 40,75 me $100 \mathrm{~g}^{-1}$ (Tabel 4). Kejenuhan Basa $(\mathrm{KB})$ pada lokasi penelitian berkisar antara 17\% - 49\% (Tabel 4). Nilai pH pada semua SPT termasuk ke dalam kategori masam. Nilai $\mathrm{pH}$ pada lokasi penelitian berkisar antara 4,06 sampai 5,34 (Tabel 4). Menurut Ritung et al. (2011), nilai pH tanah tanah pada setiap SPT di lokasi penelitian termasuk ke dalam kelas S1, S2 dan S3. Kadar C-Organik di lokasi penelitian berkisar antara 1,26\% - 16,77\% (Tabel 4), sehingga termasuk ke dalam kelas kesesuaian S1, S2 dan S3. Hara tersedia (na) ditentukan oleh nilai Nitrogen total tanah, kadar $\mathrm{P}_{2} \mathrm{O}_{5}$, dan kalium yang dapat dipertukarkan. Hasil penelitian menunjukkan bahwa kadar Ntotal di lokasi penelitian berada pada kisaran $0,07-0,21 \%$ (Tabel 5).

Tabel 3. Karakteristik lahan.

\begin{tabular}{|c|c|c|c|c|c|c|c|c|c|c|}
\hline SPT & $\begin{array}{l}\text { Taksa } \\
\text { tanah }\end{array}$ & $\begin{array}{l}\text { Suhu } \\
\left({ }^{\circ} \mathrm{C}\right)\end{array}$ & KKL & Drainase & KKL & $\begin{array}{c}\text { Solum } \\
\text { Tanah } \\
\text { (cm) }\end{array}$ & KKL & Tekstur & Kelas & KKL \\
\hline 1 & Typic Dystrudepts & 24 & S1 & $\mathrm{AB}$ & S1 & 117 & S1 & SiL & $\mathrm{S}$ & S1 \\
\hline 2 & Typic Humudepts & 23 & $\mathrm{~S} 1$ & AL & $\mathrm{S} 2$ & 119 & $\mathrm{~S} 1$ & CL & $\mathrm{AH}$ & $\mathrm{S} 1$ \\
\hline 3.1 & Typic Dystrudepts & 23 & S1 & $\mathrm{AL}$ & $\mathrm{S} 2$ & 124 & $\mathrm{~S} 1$ & CL & $\mathrm{AH}$ & $\mathrm{S} 1$ \\
\hline 3.2 & Typic Humudepts & 23 & S1 & $\mathrm{AB}$ & S1 & 115 & $\mathrm{~S} 1$ & CL & $\mathrm{AH}$ & $\mathrm{S} 1$ \\
\hline 4.1 & Typic Humudepts & 23 & $\mathrm{~S} 1$ & $\mathrm{AB}$ & $\mathrm{S} 1$ & 104 & $\mathrm{~S} 1$ & $\mathrm{C}$ & $\mathrm{H}$ & $\mathrm{S} 1$ \\
\hline 4.2 & Humic Dystrudepts & 23 & S1 & $\mathrm{AB}$ & $\mathrm{S} 1$ & 118 & $\mathrm{~S} 1$ & CL & $\mathrm{AH}$ & $\mathrm{S} 1$ \\
\hline 5.1 & Typic Dystrudepts & 22 & S1 & $\mathrm{AB}$ & $\mathrm{S} 1$ & 125 & $\mathrm{~S} 1$ & $\mathrm{C}$ & $\mathrm{H}$ & $\mathrm{S} 1$ \\
\hline 5.2 & Typic Humudepts & 22 & S1 & $\mathrm{AB}$ & $\mathrm{S} 1$ & 121 & $\mathrm{~S} 1$ & $\mathrm{C}$ & $\mathrm{H}$ & $\mathrm{S} 1$ \\
\hline 5.3 & Humic Dystrudepts & 22 & S1 & $\mathrm{AB}$ & $\mathrm{S} 1$ & 114 & $\mathrm{~S} 1$ & CL & $\mathrm{AH}$ & $\mathrm{S} 1$ \\
\hline 6.1 & Typic Humudepts & 21 & $\mathrm{~S} 1$ & $\mathrm{AB}$ & $\mathrm{S} 1$ & 113 & $\mathrm{~S} 1$ & $\mathrm{SiC}$ & $\mathrm{H}$ & $\mathrm{S} 1$ \\
\hline 6.2 & Typic Dystrudepts & 21 & S1 & $\mathrm{AB}$ & $\mathrm{S} 1$ & 116 & $\mathrm{~S} 1$ & $\mathrm{C}$ & $\mathrm{H}$ & $\mathrm{S} 1$ \\
\hline 6.3 & Humic Dystrudepts & 21 & $\mathrm{~S} 1$ & $\mathrm{AB}$ & $\mathrm{S} 1$ & 123 & $\mathrm{~S} 1$ & $\mathrm{C}$ & $\mathrm{H}$ & $\mathrm{S} 1$ \\
\hline 7.1 & Humic Dystrudepts & 21 & S1 & $A B$ & $\mathrm{~S} 1$ & 118 & $\mathrm{~S} 1$ & CL & $\mathrm{AH}$ & $\mathrm{S} 1$ \\
\hline 7.2 & Typic Humudepts & 21 & $\mathrm{~S} 1$ & $\mathrm{AB}$ & $\mathrm{S} 1$ & 121 & $\mathrm{~S} 1$ & $\mathrm{C}$ & $\mathrm{H}$ & $\mathrm{S} 1$ \\
\hline 7.3 & Typic Hapludands & 21 & S1 & $\mathrm{AB}$ & $\mathrm{S} 1$ & 128 & $\mathrm{~S} 1$ & $\mathrm{SiC}$ & $\mathrm{S}$ & $\mathrm{S} 1$ \\
\hline 8.1 & Typic Humudepts & 21 & $\mathrm{~S} 1$ & $\mathrm{AB}$ & $\mathrm{S} 1$ & 115 & $\mathrm{~S} 1$ & $\mathrm{C}$ & $\mathrm{H}$ & $\mathrm{S} 1$ \\
\hline 8.2 & Humic Dystrudepts & 21 & $\mathrm{~S} 1$ & $\mathrm{AB}$ & $\mathrm{S} 1$ & 133 & S1 & $\mathrm{C}$ & $\mathrm{H}$ & $\mathrm{S} 1$ \\
\hline 8.3 & Typic Dystrudepts & 21 & S1 & $\mathrm{AB}$ & $\mathrm{S} 1$ & 120 & $\mathrm{~S} 1$ & C & $\mathrm{H}$ & $\mathrm{S} 1$ \\
\hline
\end{tabular}

Keterangan : SPT : Satuan Peta Tanah; KKL : Kelas Kesesuaian Lahan; AB : Agak Baik ; AL : Agak Lambat; S : Sedang ; AH : Agak Halus; H : Halus ; SiL : Silt Loam (Lempung berdebu); SiC : Silt Clay (Liat berdebu); C Clay (Liat); CL : Clay Loam (Lempung berliat). 
Jurnal Tanah dan Sumberdaya Lahan Vol 8 No 1: 149-160, 2021

e-ISSN:2549-9793, doi: 10.21776/ub.jts1.2021.008.1.18

Tabel 4. Nilai KTK, KB, pH dan C-organik.

\begin{tabular}{|c|c|c|c|c|c|c|c|c|c|}
\hline SPT & Taksa tanah & $\begin{array}{c}\text { KTK } \\
(\mathrm{me} 100 \\
\left.\mathrm{g}^{-1}\right)\end{array}$ & KKL & $\begin{array}{l}\text { KB } \\
(\%)\end{array}$ & KKL & $\begin{array}{c}\mathrm{pH} \\
\mathbf{H}_{2} \mathbf{O}\end{array}$ & KKL & $\begin{array}{c}\mathrm{C}- \\
\text { Organik } \\
(\%)\end{array}$ & KKL \\
\hline 1 & Typic Dystrudepts & 29,45 & S1 & 27 & S3 & 5,90 & S1 & 1,03 & S2 \\
\hline 2 & Typic Humudepts & 32,76 & S1 & 22 & S3 & 5,68 & S2 & 0,09 & S3 \\
\hline 3.1 & Typic Dystrudepts & 29,97 & S1 & 42 & $\mathrm{~S} 2$ & 5,26 & S3 & 0,18 & S1 \\
\hline 3.2 & Typic Humudepts & 32,75 & S1 & 18 & S3 & 5,39 & S3 & 1,36 & S2 \\
\hline 4.1 & Typic Humudepts & 30,17 & S1 & 25 & S3 & 4,85 & S3 & 1,02 & S2 \\
\hline 4.2 & Humic Dystrudepts & 28,35 & S1 & 30 & S3 & 4,91 & S3 & 0,36 & S3 \\
\hline 5.1 & Typic Dystrudepts & 20,67 & S1 & 31 & S3 & 4,41 & S3 & 1,02 & S2 \\
\hline 5.2 & Typic Humudepts & 29,23 & S1 & 17 & S3 & 4,21 & S3 & 1,30 & S1 \\
\hline 5.3 & Humic Dystrudepts & 34,56 & S1 & 45 & S2 & 5,20 & S3 & 1,39 & S1 \\
\hline 6.1 & Typic Humudepts & 35,20 & S1 & 43 & S2 & 4,52 & S3 & 2,53 & S1 \\
\hline 6.2 & Typic Dystrudepts & 32,78 & S1 & 49 & S2 & 4,65 & S3 & 1,50 & S1 \\
\hline 6.3 & Humic Dystrudepts & 23,28 & S1 & 41 & S2 & 4,47 & S3 & 1,09 & S2 \\
\hline 7.1 & Humic Dystrudepts & 34,98 & S1 & 47 & S2 & 5,17 & S3 & 0,94 & S2 \\
\hline 7.2 & Typic Humudepts & 36,86 & S1 & 29 & S3 & 5,10 & S3 & 1,58 & S1 \\
\hline 7.3 & Typic Hapludands & 28,03 & S1 & 19 & S3 & 4,96 & S3 & 1,25 & S1 \\
\hline 8.1 & Typic Humudepts & 34,65 & S1 & 29 & S3 & 5,35 & S3 & 1,11 & S2 \\
\hline 8.2 & Humic Dystrudepts & 34,55 & S1 & 26 & S3 & 5,19 & S3 & 0,46 & S3 \\
\hline 8.3 & Typic Dystrudepts & 40,75 & S1 & 22 & S3 & 5,04 & S3 & 0,28 & S3 \\
\hline
\end{tabular}

Keterangan : KKL : Kelas Kesesuaian Lahan berdasarkan Ritung et al. (2011)

Berdasarkan kriteria Ritung et al. (2011) seluruh SPT termasuk ke dalam kelas kesesuaian S3 karena seluruh SPT memiliki nilai $\mathrm{P}_{2} \mathrm{O}_{5}$ dengan kategori sangat rendah. Kadar K-dd pada lokasi penelitian berkisar antara 0,22 - 1,93 (Tabel 5). Berdasarkan kriteria Ritung et al. (2011) kesesuaian lahan termasuk ke dalam kelas S1, S2 dan S3. Bahaya erosi dapat ditentukan dari kelas bahaya erosi aktual di lapangan dan kelerengan lahan. Pada lokasi penelitian ditemukan 2 kategori kelas bahaya erosi yaitu sangat ringan dan ringan sehingga berdasarkan kriteria Ritung et al. (2011) kelas kesesuaian lahan pada lokasi penelitian termasuk ke dalam kelas S2 dan S3 (Tabel 6). Kemiringan lereng yang ditemukan pada lokasi penelitian berada pada kisaran $2 \%$ $20 \%$ (Tabel 6) sehingga menurut Ritung et al. (2011) termasuk ke dalam 3 kelas kesesuaian lahan yaitu S2, S3, dan N.

\section{Kesesuaian lahan aktual tanaman jagung}

Menurut kriteria Ritung et al. (2011) kelas kesesuaian lahan aktual untuk tanaman jagung pada lokasi penelitian termasuk ke dalam kelas S3 dan N. Faktor faktor pembatas yang ada yaitu curah hujan, C-organik, $\mathrm{pH}$, Kejenuhan Basa, N-total, $\mathrm{P}_{2} \mathrm{O}_{5}, \mathrm{~K}$-dd, bahaya erosi, dan lereng (Tabel 7). Curah hujan menjadi faktor pembatas karena curah hujan tahunan rata rata di lokasi penelitian terlalu tinggi, menurut Wirosoedarmo et al. (2011) curah hujan yang tinggi mengakibatkan pencucian kation basa dari lapisan permukaan tanah ke lapisan tanah yang lebih dalam sehingga $\mathrm{pH}$ tanah akan menjadi masam. C-organik menjadi faktor pembatas karena terdapat beberapa SPT yang memiliki kadar C-organik rendah. Menurut Wirosoedarmo et al. (2011) semakin banyak jumlah bahan organik maka agregat semakin mantap hal ini disebabkan bahan organik merupakan bahan perekat yang dapat memantapkan agregat tanah serta mempunyai nilai konsistensi yang baik, karena mampu mempertahankan struktur tanah. $\mathrm{pH}$ menjadi faktor pembatas karena tanah pada lokasi penelitian termasuk ke dalam kategori asam. Menurut Wirosoedarmo et al. (2011) nilai derajat keasaman tanah $(\mathrm{pH})$ penting untuk menentukan mudah tidaknya unsur-unsur hara diserap tanaman. $\mathrm{pH}$ yang asam menyebabkan tersedianya unsur beracun seperti alumunium yang selalu meracuni tanaman dan juga mengikat fosfor sehingga tidak bisa diserap oleh tanaman. Kejenuhan Basa menjadi faktor pembatas karena pada beberapa SPT nilai KB rendah. 
Jurnal Tanah dan Sumberdaya Lahan Vol 8 No 1: 149-160, 2021

e-ISSN:2549-9793, doi: 10.21776/ub.jts1.2021.008.1.18

Tabel 5. Kadar N-total, $\mathrm{P}_{2} \mathrm{O}_{5}$ dan K-dd.

\begin{tabular}{|c|c|c|c|c|c|c|c|}
\hline SPT & Taksa tanah & $\begin{array}{c}\text { N-total } \\
(\%)\end{array}$ & KKL & $\begin{array}{c}\mathrm{P}_{2} \mathrm{O}_{5} \\
\left(\mathrm{mg} \mathrm{kg}^{-1}\right)\end{array}$ & KKL & $\begin{array}{c}\text { K-dd } \\
\left(\mathrm{me} 100 \mathrm{~g}^{-1}\right)\end{array}$ & KKL \\
\hline 1 & Typic Dystrudepts & 0,08 & $\mathrm{S3}$ & 2,40 & S3 & 0,76 & S1 \\
\hline 2 & Typic Humudepts & 0,07 & S3 & 1,55 & S3 & 0,57 & S1 \\
\hline 3.1 & Typic Dystrudepts & 0,08 & S3 & 3,14 & S3 & 0,70 & S1 \\
\hline 3.2 & Typic Humudepts & 0,08 & S3 & 2,32 & S3 & 0,22 & S3 \\
\hline 4.1 & Typic Humudepts & 0,10 & S2 & 0,79 & S3 & 0,94 & S1 \\
\hline 4.2 & Humic Dystrudepts & 0,07 & S3 & 1,54 & S3 & 0,84 & S1 \\
\hline 5.1 & Typic Dystrudepts & 0,10 & S2 & 1,60 & S3 & 1,24 & S1 \\
\hline 5.2 & Typic Humudepts & 0,14 & S2 & 2,38 & S3 & 0,54 & S2 \\
\hline 5.3 & Humic Dystrudepts & 0,10 & S2 & 0,79 & S3 & 1,93 & S1 \\
\hline 6.1 & Typic Humudepts & 0,21 & S1 & 1,67 & S3 & 0,82 & S1 \\
\hline 6.2 & Typic Dystrudepts & 0,14 & S2 & 0,80 & S3 & 0,27 & S3 \\
\hline 6.3 & Humic Dystrudepts & 0,11 & S2 & 2,33 & S3 & 0,77 & S1 \\
\hline 7.1 & Humic Dystrudepts & 0,12 & S2 & 0,80 & S3 & 0,96 & S1 \\
\hline 7.2 & Typic Humudepts & 0,17 & S2 & 3,18 & S3 & 1,64 & S1 \\
\hline 7.3 & Typic Hapludands & 0,14 & S2 & 3,57 & S3 & 0,34 & S3 \\
\hline 8.1 & Typic Humudepts & 0,11 & S2 & 0,79 & S3 & 0,75 & S1 \\
\hline 8.2 & Humic Dystrudepts & 0,16 & S2 & 1,58 & S3 & 0,46 & S1 \\
\hline 8.3 & Typic Dystrudepts & 0,13 & S2 & 2,36 & S3 & 0,62 & S1 \\
\hline
\end{tabular}

Keterangan : KKL : Kelas Kesesuaian Lahan berdasarkan Ritung et al. (2011).

Tabel 6. Kelas bahaya erosi dan kelerengan.

\begin{tabular}{clcccc}
\hline SPT & Taksa tanah & Kelas Erosi & KKL & Lereng (\%) & KKL \\
\hline 1 & Typic Dystrudepts & Sangat Ringan & S2 & 2 & S1 \\
2 & Typic Humudepts & Sangat Ringan & S2 & 9 & S3 \\
3.1 & Typic Dystrudepts & Ringan & S3 & 10 & S3 \\
3.2 & Typic Humudepts & Sangat Ringan & S2 & 10 & S3 \\
4.1 & Typic Humudepts & Ringan & S3 & 10 & S3 \\
4.2 & Humic Dystrudepts & Sangat Ringan & S2 & 10 & S3 \\
5.1 & Typic Dystrudepts & Ringan & S3 & 11 & S3 \\
5.2 & Typic Humudepts & Ringan & S3 & 11 & S3 \\
5.3 & Humic Dystrudepts & Sangat Ringan & S2 & 11 & S3 \\
6.1 & Typic Humudepts & Sangat Ringan & S2 & 12 & S3 \\
6.2 & Typic Dystrudepts & Ringan & S3 & 12 & S3 \\
6.3 & Humic Dystrudepts & Ringan & S3 & 12 & S3 \\
7.1 & Humic Dystrudepts & Ringan & S3 & 11 & S3 \\
7.2 & Typic Humudepts & Ringan & S3 & 11 & S3 \\
7.3 & Typic Hapludands & Ringan & S3 & 20 & N \\
8.1 & Typic Humudepts & Ringan & S3 & 14 & S3 \\
8.2 & Humic Dystrudepts & Ringan & S3 & 14 & S3 \\
8.3 & Typic Dystrudepts & Ringan & S3 & 14 & S3 \\
\hline
\end{tabular}

Keterangan : KKL : Kelas Kesesuaian Lahan berdasarkan Ritung et al. (2011)

Menurut Nora (2016) tanah dengan kejenuhan basa rendah menandakan tanah tersebut asam sehingga menghambat penyerapan unsur hara oleh akar tanaman. Nilai N-total yang rendah pada beberapa SPT menjadi alasan kenapa Ntotal menjadi faktor pembatas. Penggunaan pupuk $\mathrm{N}$ oleh tanaman serealia kurang efisien, umumnya kurang dari $50 \%$ dari total $\mathrm{N}$ yang diberikan. Penyebab utamanya adalah Nitrogen hilang dari sistem tanaman-tanah melalui pencucian, limpasan, erosi, denitrifikasi, penguapan $\mathrm{NH} 3$ atau emisi gas $\mathrm{N}_{2} \mathrm{O}$ 


\section{Jurnal Tanah dan Sumberdaya Lahan Vol 8 No 1: 149-160, 2021 e-ISSN:2549-9793, doi: 10.21776/ub.jts1.2021.008.1.18}

(Syafruddin 2015). $\mathrm{P}_{2} \mathrm{O}_{5}$ pada seluruh SPT termasuk ke dalam kategori rendah sehingga menjadi faktor pembatas dalam pertumbuhan jagung, Pada tanah masam unsur hara $\mathrm{P}$ tidak dapat diserap karena diikat (difiksasi) oleh $\mathrm{Al}$ dan Fe (Hamka et al., 2015). Kadar K-dd pada beberapa SPT termasuk ke dalam kategori rendah, hal tersebut berakibat K-dd menjadi salah satu faktor pembatas. Menurut Kaya (2014) Kalium diserap oleh tanaman dalam jumlah yang cukup besar. Oleh karena itu apabila kalium di dalam tanah dan yang berasal dari air irigasi tidak mencukupi untuk pertumbuhan, maka tanaman akan menderita karena kekurangan kalium dan produksinya akan rendali. Bahaya erosi menjadi faktor pembatas karena terdapat beberapa SPT yang memiliki kelas erosi ringan sehingga menjadi faktor pembatas. Menurut Fuady et al. (2014) erosi membawa lapisan tanah permukaan yang umumnya lebih subur, kaya bahan organik dan unsur hara sehingga menyebabkan hilangnya unsur hara bagi tanaman. Lereng menjadi faktor pembatas karena pada lokasi penelitian rata rata nilai lereng lebih dari 10\%, Menurut Wirosoedarmo et al. (2011) Karakteristik lereng ini berhubungan dengan sifat morfologi lahan. Topografi landai memiliki agregat tanah lebih mantap daripada yang berlereng curam, sebab pada topografi yang berlereng curam sering terjadi erosi sehingga bahan organik yang merupakan perekat-perekat agregat hilang sehingga kemantapan agregat tanah menjadi lemah.

\section{Produktivitas tanaman jagung}

Produktivitas jagung varietas Bisi-2 pada lokasi penelitian berada pada kisaran 4,1 - 8,9 t ha- ${ }^{1}$. Nilai presentase produktivitas didapatkan dari perhitungan produktivitas aktual tanaman jagung per SPT dibagi dengan potensi produktivitas jagung kemudian dikalikan dengan $100 \%$. Potensi produktivitas jagung varietas Bisi-2 adalah $13 \mathrm{t} \mathrm{ha}^{-1}$ Keterangan produktivitas Jagung beserta kelas kesesuaian lahannya dapat dilihat pada Tabel 8.

\section{Analisis garis batas untuk modifikasi kriteria evaluasi kesesuaian lahan}

Berdasarkan analisis korelasi dan regresi dengan menggunakan software SPKL versi 25 didapatkan beberapa faktor yang mempengaruhi produktivitas jagung pada lokasi penelitian yaitu lereng dan temperatur. Nilai signifikansi lereng dengan produktivitas jagung adalah sebesar 0,000 dengan nilai koefisien determinasi sebesar 0,591 dan temperatur dengan produktivitas jagung memiliki nilai signifikansi 0,012 dengan nilai koefisien determinasi sebesar 0,429. Menurut penarikan garis batas (Gambar 2) didapatkan nilai hasil modifikasi yaitu nilai lereng $0-9 \%$ termasuk ke dalam kelas S2, nilai lereng $9-18 \%$ termasuk ke dalam kelas S3 dan nilai lereng $>18 \%$ termasuk ke dalam kelas $\mathrm{N}$.

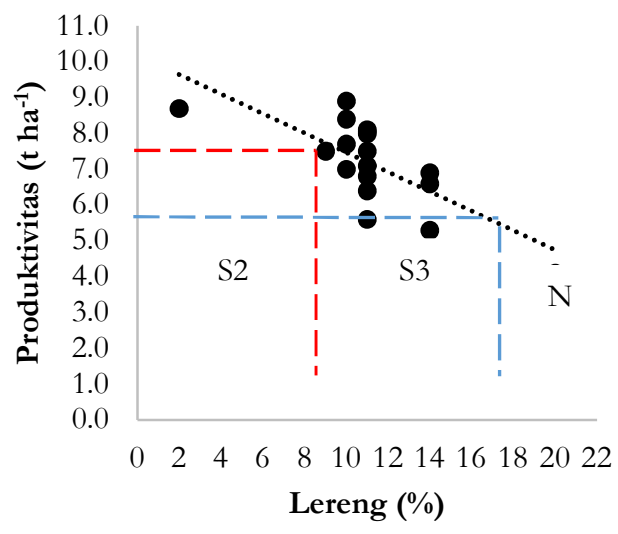

Gambar 2. Analisis garis batas lereng.

\section{Kriteria kesesuaian lahan jagung hasil modifikasi analisis garis batas}

Tabel 9 menunjukkan kriteria hasil modifikasi berdasarkan analisis garis batas. Nilai lereng berdasarkan kriteria Ritung et al. (2011) menunjukkan bahwa nilai lereng $<3$ (S1), 3-8 (S2), 8-15 (S3) dan $>15 \quad$ (N). Setelah dimodifikasi, kriteria lereng menjadi 0-9 termasuk kelas S2, 9-18 termasuk kelas S3 dan $>18$ termasuk ke dalam kelas $\mathrm{N}$.

Keselarasan hasil evaluasi lahan menggunakan kriteria sebelum dan sesudah modifikasi dengan data produksi

Berdasarkan kriteria hasil modifikasi, seluruh SPT memiliki kelas kesesuaian yang sama dengan kelas kesesuaian berdasarkan kriteria Ritung et al. (2011) dan terdapat 3 SPT yang tidak sesuai dengan kelas kesesuaian lahan berdasarkan produksi jagung diantaranya SPT 1, 3.1, dan 4.2. 


\section{Jurnal Tanah dan Sumberdaya Lahan Vol 8 No 1: 149-160, 2021 e-ISSN:2549-9793, doi: 10.21776/ub.jts1.2021.008.1.18}

Tabel 8. Kelas kesesuaian actual.

\begin{tabular}{|c|c|c|c|}
\hline SPT & Taksa tanah & KKL & Faktor Pembatas \\
\hline 1 & Typic Dystrudepts & S3 & Curah hujan, $\mathrm{pH}, \mathrm{KB}, \mathrm{N}$-total, $\mathrm{P}_{2} \mathrm{O}_{5}, \mathrm{~K}$-dd \\
\hline 2 & Typic Humudepts & S3 & Curah hujan, $\mathrm{KB}, \mathrm{pH}, \mathrm{C}$-Organik, $\mathrm{N}$-total, $\mathrm{P}_{2} \mathrm{O}_{5}, \mathrm{~K}$-dd, lereng \\
\hline \multirow[t]{3}{*}{3} & Asosiasi & S3 & Curah hujan, $\mathrm{KB}, \mathrm{pH}, \mathrm{N}$-total, $\mathrm{P}_{2} \mathrm{O}_{5}, \mathrm{~K}$-dd, lereng, bahaya erosi \\
\hline & Typic Dystrudepts & & \\
\hline & Typic Humudepts & S3 & Curah hujan, pH, C-Organik, N-total, $\mathrm{P}_{2} \mathrm{O}_{5}, \mathrm{~K}$-dd, lereng \\
\hline \multirow[t]{3}{*}{4} & Asosiasi & & \\
\hline & Typic Humudepts & S3 & Curah hujan, $\mathrm{KB}, \mathrm{pH}, \mathrm{N}$-total, $\mathrm{P}_{2} \mathrm{O}_{5}, \mathrm{~K}$-dd, lereng, bahaya erosi \\
\hline & Humic Dystrudepts & S3 & Curah hujan, $\mathrm{pH}, \mathrm{KB}, \mathrm{C}$-Organik, $\mathrm{N}$-total, $\mathrm{P}_{2} \mathrm{O}_{5}, \mathrm{~K}$-dd, lereng \\
\hline \multirow[t]{4}{*}{5} & Asosiasi & & \\
\hline & Typic Dystrudepts & S3 & Curah hujan, $\mathrm{KB}, \mathrm{pH}, \mathrm{P}_{2} \mathrm{O}_{5} \mathrm{~K}$-dd, lereng, bahaya erosi \\
\hline & Typic Humudepts & S3 & Curah hujan, $\mathrm{KB}, \mathrm{pH}, \mathrm{P}_{2} \mathrm{O}_{5}, \mathrm{~K}$-dd, lereng, bahaya erosi \\
\hline & Humic Dystrudepts & S3 & Curah hujan, $\mathrm{pH}, \mathrm{N}$-total, $\mathrm{P}_{2} \mathrm{O}_{5}, \mathrm{~K}$-dd, lereng \\
\hline \multirow[t]{4}{*}{6} & Kompleks & & \\
\hline & Typic Humudepts & S3 & Curah hujan, $\mathrm{pH}, \mathrm{P}_{2} \mathrm{O}_{5}, \mathrm{~K}$-dd, lereng \\
\hline & Typic Dystrudepts & S3 & Curah hujan, $\mathrm{pH}, \mathrm{P}_{2} \mathrm{O}_{5}, \mathrm{~K}$-dd, lereng, bahaya erosi \\
\hline & Humic Dystrudepts & S3 & Curah hujan, $\mathrm{pH}, \mathrm{P}_{2} \mathrm{O}_{5}, \mathrm{~K}$-dd, lereng, bahaya erosi \\
\hline \multirow[t]{4}{*}{7} & Kompleks & & \\
\hline & Humic Dystrudepts & S3 & Curah hujan, $\mathrm{KB}, \mathrm{pH}, \mathrm{P}_{2} \mathrm{O}_{5}, \mathrm{~K}$-dd, lereng, bahaya erosi \\
\hline & Typic Humudepts & S3 & Curah hujan, $\mathrm{KB}, \mathrm{pH}, \mathrm{P}_{2} \mathrm{O}_{5}, \mathrm{~K}$-dd, lereng, bahaya erosi \\
\hline & Typic Hapludands & $\mathrm{N}$ & Lereng \\
\hline \multirow[t]{4}{*}{8} & Kompleks & & \\
\hline & Typic Humudepts & S3 & Curah hujan, $\mathrm{KB}, \mathrm{pH}, \mathrm{P}_{2} \mathrm{O}_{5}, \mathrm{~K}$-dd, lereng, bahaya erosi \\
\hline & Humic Dystrudepts & S3 & $\begin{array}{l}\text { Curah hujan, } \mathrm{KB}, \mathrm{pH}, \mathrm{C}-\mathrm{Organik}, \mathrm{P}_{2} \mathrm{O}_{5} \text {, } \mathrm{K} \text {-dd, lereng, bahaya } \\
\text { erosi }\end{array}$ \\
\hline & Typic Dystrudepts & S3 & $\begin{array}{l}\text { Curah hujan, } \mathrm{KB}, \mathrm{pH}, \mathrm{C}-\text { Organik, } \mathrm{P}_{2} \mathrm{O}_{5}, \mathrm{~K} \text {-dd, lereng, bahaya } \\
\text { erosi }\end{array}$ \\
\hline
\end{tabular}

Keterangan : KKL : Kelas Kesesuaian Lahan berdasarkan Ritung et al. (2011)

Tabel 7. Produktivitas jagung Kecamatan Wagir.

\begin{tabular}{clccc}
\hline SPT & Taksa tanah & Produktivitas $\mathbf{( t ~ h a - 1 )}$ & Presentase Produktivitas & KKL \\
\hline 1 & Typic Dystrudepts & 8,7 & 66,92 & $\mathrm{~S} 2$ \\
2 & Typic Humudepts & 7,5 & 57,69 & $\mathrm{~S} 3$ \\
3.1 & Typic Dystrudepts & 8,9 & 53,85 & $\mathrm{~S} 3$ \\
3.2 & Typic Humudepts & 7,0 & 68,46 & $\mathrm{~S} 2$ \\
4.1 & Typic Humudepts & 7,7 & 59,23 & $\mathrm{~S} 3$ \\
4.2 & Humic Dystrudepts & 8,4 & 64,62 & $\mathrm{~S} 2$ \\
5.1 & Typic Dystrudepts & 7,5 & 43,08 & $\mathrm{~S} 3$ \\
5.2 & Typic Humudepts & 5,6 & 57,69 & $\mathrm{~S} 3$ \\
5.3 & Humic Dystrudepts & 7,1 & 54,62 & $\mathrm{~S} 3$ \\
6.1 & Typic Humudepts & 7,7 & 59,23 & $\mathrm{~S} 3$ \\
6.2 & Typic Dystrudepts & 7,7 & 59,23 & $\mathrm{~S} 3$ \\
6.3 & Humic Dystrudepts & 7,5 & 57,69 & $\mathrm{~S} 3$ \\
7.1 & Humic Dystrudepts & 6,8 & 52,31 & $\mathrm{~S} 3$ \\
7.2 & Typic Humudepts & 6,4 & 49,23 & $\mathrm{~S} 3$ \\
7.3 & Typic Hapludands & 4,1 & 31,54 & $\mathrm{~N}$ \\
8.1 & Typic Humudepts & 5,3 & 40,77 & $\mathrm{~S} 3$ \\
8.2 & Humic Dystrudepts & 6,6 & 50,77 & $\mathrm{~S} 3$ \\
8.3 & Typic Dystrudepts & 6,9 & 53,08 & $\mathrm{~S} 3$ \\
\hline
\end{tabular}

Keterangan : KKL : Kelas Kesesuaian Lahan berdasarkan Ritung et al. (2011) 


\section{Jurnal Tanah dan Sumberdaya Lahan Vol 8 No 1: 149-160, 2021 e-ISSN:2549-9793, doi: 10.21776/ub.jts1.2021.008.1.18}

Tabel 9. Karakteristik lereng hasil modifikasi.

\begin{tabular}{lcccc}
\hline Karakteristik & \multicolumn{5}{c}{ KelasKesesuaian Lahan } \\
\cline { 2 - 5 } Lahan & S1 & S2 & S3 & N \\
\hline $\begin{array}{l}\text { Bahaya erosi (eh) } \\
\text { Lereng }(\%)\end{array}$ & & $0-9$ & $9-18$ & $>18$ \\
\hline
\end{tabular}

Upaya perbaikan terhadap faktor pembatas

Berdasarkan analisis yang dilakukan, faktor pembatas antara lain dari karakteristik temperatur yaitu curah hujan, karakteristik retensi hara yaitu kejenuhan basa, $\mathrm{pH}$ dan COrganik, kemudian dari karakteristik hara tersedia yaitu $\mathrm{N}$-total, $\mathrm{P}_{2} \mathrm{O}_{5}, \mathrm{~K}$-dd, serta dari karakteristik bahaya erosi yaitu lereng dan bahaya erosi aktual. Perbaikan faktor pembatas curah hujan dapat dilakukan dengan penataan pola tanam, perbaikan drainase serta perbaikan sistem irigasi. Perbaikan faktor pembatas retensi hara yang meliputi kejenuhan basa, $\mathrm{pH}$, dan $\mathrm{C}$ Organik dapat dilakukan dengan pengapuran dan penambahan bahan organik tanah. Perbaikan faktor pembatas hara tersedia yang meliputi N-total, $\mathrm{P}_{2} \mathrm{O}_{5}$ dan $\mathrm{K}$-dd dapat dilakukan dengan pemupukan secara seimbang dengan dosis yang tepat serta waktu yang tepat pula. Menurut penelitian Pusparini et.al. (2018) dosis NPK yang optimum untuk pertumbuhan dan hasil jagung adalah sekitar $300 \mathrm{~kg}$ ha-1 (8,92 t ha-1). Perbaikan faktor pembatas bahaya erosi yang meliputi lereng dan bahaya erosi aktual dapat dilakukan dengan membuat terasering, penanaman sejajar kontur, pengolahan tanah menurut kontur, penanaman penutup tanah.

\section{Kesimpulan}

Kelas kesesuaian lahan aktual di Kecamatan Wagir berdasarkan kriteria Ritung et al. (2011) termasuk ke dalam kelas S3 dan N. Faktorfaktor pembatas pada kelas kesesuaian tersebut antara lain curah hujan, kejenuhan basa, pH, Corganik, N-total, $\mathrm{P}_{2} \mathrm{O}_{5}, \mathrm{~K}$-dd, lereng serta bahaya erosi. Karakteristik lahan yang paling berpengaruh terhadap produktivitas jagung di Kecamatan Wagir adalah lereng dan temperatur. Kelas kesesuaian lahan berdasarkan presentase produksi tanaman jagung, masuk ke dalam kelas S2, S3 dan $\mathrm{N}$ dengan rentang produksi berkisar antara 31,54\% sampai 68,48\%. Karakteristik lahan yang dimodifikasi pada kriteria hasil analisis boundary line yaitu lereng (S2: 0-9, S3: 918, dan N: $>18$.

\section{Daftar Pustaka}

Association of Official Agriculture Chemists. 2002. Official Methods of Analysis of AOAC international In Horwitz, W. (Ed.). Agricultural Chemicals, Contaminants, Drugs. AOAC International, Maryland, USA. 17th ed. p. 25-27.

BPS. 2017. Provinsi Jawa Timur dalam Angka Tahun 2017. Badan Pusat Statistik Kabupaten Malang.

Bray, R.H. and Kurtz, L.T. 1945. Determination of total organik and available forms of phosphorus in soils. Soil Science $59: 39-45$.

FAO. 1976. A Framework for Land Evaluation. Food and Agriculture Organization of the United Nations, Soil Buletin 32. FAO, Rome. Italy

Fuady, H., Halus, S. dan Nanda., M. 2014. Aliran permukaan, erosi dan hara sedimen akibat tindakan konservasi tanah vegetatif pada kelapa sawit. Jurnal Ilmu Tanah dan Agroklimat 11(2) : 95-103.

Hajek, B.F., Adams, F. and Cope, J.T. 1972. Rapid determination of exchangeable bases, acidity and cation exchange capacity. Soil Science $36: 436$ 438.

Hamka., Wardah., dan Rachman, I. 2015. Evaluasi kesesuaian lahan untuk pengembangan hutan rakyat di Desa Beraban Kabupaten Parigi Moutong. Jurnal Sains dan Teknologi Tadulako 4(2) : 16-25.

ISRIC, 1993. Procedures for Soil Analysis. In: van Reeuwijk, L.P. (Ed.) Technical Paper, International Soil Reference and Information Centre. Wageningen, The Netherlands. 4th ed. p.100.

Kaya, E. 2014. Pengaruh pupuk organik dan pupuk NPK terhadap $\mathrm{pH}$ dan K-tersedia tanah serta serapan-K, pertumbuhan, dan hasil padi sawah (Oryza sativa L.). Buana Sains 14(2) : 113-122.

Nora, S. 2016. evaluasi kesesuaian lahan kering di Kecamatan Hamparan Perak Kabupaten Deli Serdang. Jurnal Agrica Ekstensia 10(2) : 19-28.

Pusparini, P.G., Ahmad, Y. dan Dwi, J. 2018. Dosis pupuk NPK terhadap pertumbuhan dan hasil jagung hibrida. Jurnal Agrosains 20(2) : 28-33.

Ritung, S., Nugroho, K., Mulyani, A. dan Suryani, E. 2011. Petunjuk Teknis Evaluasi Lahan untuk Komoditas Pertanian. Balai Besar Penelitian dan Pengembangan Sumberdaya Lahan Pertanian. Bogor.

Soil Survey Staff. 2014. Kunci Taksonomi Tanah. Edisi Ketiga, 2015. Balai Besar Penelitian dan Pengembangan Sumberdaya Lahan Pertanian, Badan Penelitian dan Pengembangan Pertanian. 
Jurnal Tanah dan Sumberdaya Lahan Vol 8 No 1: 149-160, 2021

e-ISSN:2549-9793, doi: 10.21776/ub.jts1.2021.008.1.18

Sudjadi M. dan Widjik, I.M. 1972. Metoda Analisa Air Irigasi. Publikasi 8/72, Lembaga Penelitian Tanah, Bogor.

Syafruddin. 2015. Manajemen pemupukan nitrogen pada tanaman jagung. Jurnal Litbang Pertanian 34(3) : 105-116.
Wirosoedarmo, R., Tunggul, S. A., Evi, K, dan Rizky, W. 2011. evaluasi kesesuaian lahan untuk tanaman jagung menggunakan metode analisis spasial. Jurnal Agritech 31(1) : 71-78. 